\title{
Effect of Nitriding Current Density on the Surface Properties and Crystallite Size of Pulsed Plasma-Nitrided AISI 316L
}

\author{
J. C. Díaz-Guillén1*, E. E. Granda-Gutiérrez¹, G. Vargas-Gutiérrez², M. R. Díaz-Guillén³, \\ J. A. Aguilar-Martínez ${ }^{4}$, L. Álvarez-Contreras ${ }^{5}$ \\ ${ }^{1}$ Corporación Mexicana de Investigación en Materiales S.A. de C.V.-Cátedras-CONACyT, Saltillo, México \\ ${ }^{2}$ Centro de Investigación y Estudios Avanzados del IPN, Saltillo, México \\ ${ }^{3} \mathrm{GMyPQ}$, Instituto de Investigaciones Eléctricas, Cuernavaca, México \\ ${ }^{4}$ Universidad Autónoma de Nuevo León, FIME-CIIIA, Apodaca, México \\ ${ }^{5}$ Centro de Investigación en Materiales Avanzados S.C., Chihuahua, México \\ Email: jcarlos@comimsa.com.mx
}

Received December 2014

\section{Abstract}

In this work, plasma-nitrided AISI 316L stainless steel samples were performed by ion nitriding process under pulsed direct current (DC) discharge at different current densities (1 to $2.5 \mathrm{~mA}$ / $\mathrm{cm}^{2}$ ). The effect of nitriding current density on the size of crystalline coherently diffracting domains (crystallite size) and strain grade was investigated using X-ray diffraction (XRD) coupled with Williamson-Hall method. Additionally, hardness and wear resistance of the nitriding layer were characterized using a Vickers indenter and pin-on-disk technique respectively. Results showed a decrease in crystallite size from $99 \mathrm{~nm}$ for untreated samples to $1.4 \mathrm{~nm}$ for samples nitrided at $2.5 \mathrm{~mA} / \mathrm{cm}^{2}$ promoted both: an increase in hardness from $226 \mathrm{HV}_{25 \mathrm{~g}}$ to $1245 \mathrm{HV}_{25 \mathrm{~g}}$, and a considerably decrease in volume loss by wear effect.

\section{Keywords}

Plasma Nitriding, Strain, Crystallite Size, Hardness, Wear, Stainless

\section{Introduction}

Stainless steels are well known by good corrosion resistance; unfortunately, their surface hardness and wear resistance are relatively poor and therefore insufficient for many technological applications. Plasma or ion nitriding is one of the techniques used in surface engineering to increase the surface properties of these steels. This technique uses the direct current (DC) glow discharge phenomena to introduce elemental nitrogen in the surface of metallic pieces for subsequent diffusion process into the crystalline lattice of the material.

In the last years, pulsed plasma nitriding of AISI 316L stainless steel has been used to increase its tribological

\footnotetext{
*Corresponding author.
}

How to cite this paper: Díaz-Guillén, J.C., et al. (2015) Effect of Nitriding Current Density on the Surface Properties and Crystallite Size of Pulsed Plasma-Nitrided AISI 316L. Journal of Materials Science and Chemical Engineering, 3, 45-51. 
performance and corrosion properties. It is well-established that nitrogen incorporation, into the surface of this alloy, results in the formation of a thin surface layer constituted by a meta-stable nitrogen supersaturated solid solution with a distorted crystalline lattice known as expanded austenite $\left(\gamma_{\mathrm{N}}\right)$. According to the literature, this phase $\gamma_{\mathrm{N}}$, can exhibit high strength, excellent corrosion resistance and a dramatical improvement of wear resistance under high loads [1]-[4]. In fact, the expanded austenite phase obtained by nitriding has been the subject of several studies due to its technological importance and applications [5]-[7]; however, its structure and formation mode have not been completely understood [8].

The tribological properties of nitrided austenitic stainless steel have been related to the deformation grade of FCC original austenitic lattice $(\gamma)$, which is promoted by incorporating atomic nitrogen in its interstitial octahedral sites [6] [9]. This deformation tends to increase the austenitic lattice parameters, which is supported by displacement of austenite X-ray reflections to a lower $2 \theta$ angles [10]. The strain grade of the austenitic structure is closely related to a variation in size of "crystalline coherently diffracting domains" also called crystallites [11]. Consequently, the control of strain grade and of crystallite size, becomes a primary tool when obtaining the desired surface properties of AISI 316L stainless steel.

In this work we evaluated the effect of nitriding current density on the crystallite size and strain grade of plasma nitrided austenitic stainless steel samples and the variation of both were correlated to surface hardness and wear susceptibility.

\section{Material and Methods}

Commercial AISI 316L stainless steel samples of $50 \mathrm{~mm}$ in diameter and $12.7 \mathrm{~mm}$ thick were used in the present experiment. Chemical composition of the samples was: Cr 16.6\%, Ni 10\%, Mo 2\%, Mn 1.76\%, Cu 0.38\%, Si 0.38\%, Co 0.06\%, C 0.019\%, S 0.029\%, Fe Balance (all in \% weight). Previously to nitriding treatment, all samples were ground by different grades of SiC emery paper $(120,240,320,400,600)$ and polished with a 1- $\mu \mathrm{m}$ diamond suspension. In order to remove the mechanical strain induced on the surface by mechanical polishing, a final electropolishing process, recommended by L. Nosei et al. [12], was carried out using an electrolyte containing methanol, perchloric acid and butylcellosolve during $240 \mathrm{~s}$ and current density of 0.5 $\mathrm{A} / \mathrm{cm}^{2}$. After that, samples were subjected to a cleaning stage in an acetone ultrasonic bath.

The ion nitriding process under direct current (DC) pulsed discharge was carried out in a previously described reactor [13]. The constant process parameters considered were: sample temperature of $400^{\circ} \mathrm{C}$, gas mixture of $50 \%$ $\mathrm{N}_{2}$ and $50 \% \mathrm{H}_{2}, 1000 \mathrm{~Hz}$ pulse frequency and duty cycle of $50 \%$ active. The reactor was pumped down to a base pressure of $3 \times 10^{-3}$ torr and nitriding pressure was set at 1.3 torr. Prior to the nitriding process, a cleaning stage using sputtering was carried out on the samples in the same reactor using a gas mixture of $50 \% \mathrm{Ar}_{\text {and }} 50 \% \mathrm{H}_{2}$. The effect of current density $\left(1,1.5,2\right.$ and $\left.2.5 \mathrm{~mA} / \mathrm{cm}^{2}\right)$ on strain grade and crystallite size was tested.

The strain grade and crystallite size of nitrided samples were calculated using "X” Pert High Score PlusTM” version 3.0 software, fitting the peak profiles with a pseudo-Voigt function. This software uses the diffraction data and Williamson-Hall (W-H) graphical methodology. W-H method works by considering that both, the size of the crystallites and the presence of crystallographic distortions (strain), contribute to XRD peak broadening. It is important to point out that XRD supplies information about average crystallite sizes which are domains of coherently diffracting X-rays (Perfect arrangement of unit cells or perfect crystal). This should not be confused with grain or particle size, Crystallite size and grain size are not necessarily the same. When the grain size is in the nanometer scale, the crystallite and the grain size could be the same but when grain size is bigger a grain may be composed of multiple crystallites separated by different kinds of grain boundaries [11]. Strain and crystallite size were computed by using Williamson-Hall equation:

$$
\left(B_{E X P}^{2}-B_{E Q}^{2}\right) \operatorname{Cos} \theta=M \operatorname{Sen} \theta+c \lambda / t
$$

where $B_{E X P}^{2}$ is the experimental "full width at half its maximum intensity" (FWHM), $B_{E Q}^{2}$ is FWHM due to the XRD equipment, $M$ corresponds to micro deformation and $t$ to the crystallite size [14]. In order to determine the instrumental contribution to line broadening $\left(B_{E Q}^{2}\right)$, the diffraction pattern of a cerium oxide sample from National Institute of Standards and Technology, Standard Reference Material 674A (NIST SRM) was used as an instrument standard. The instrumental set up was identical in every aspect to that used for recording the diffraction pattern of all studied samples.

It is known that XRD peak broadening can be additionally promoted by steep composition and stress gradient; 
however in this work, the influence of this will not be considered based on Saravanan et al. work [15]. They considered that influence of these gradients is significant when samples are processed at lower temperatures and longer time than used in this report.

X-ray diffraction Analysis (XRD) was performed with an Empyrean PANalytical instrument, using $\mathrm{Cu} \mathrm{K} \alpha(\lambda$ $=1.5406 \AA$ ) radiation, operated at $40 \mathrm{kV}$ and $30 \mathrm{~mA}$ and the X'Celerator ultra-fast detector based on Real Time Multiple Strip Technology with a Bragg-Brentano geometry. The scanning was conducted with a step scan of $0.016^{\circ}$ and dwell time of $20 \mathrm{~s}$ per step in continuous mode. Likewise, the untreated sample (reference material) was ground and polished in the same way as the nitrided samples. The effect of the total strain of the X-ray diffraction broadening in the present work was carried out in a comparative way. After ion nitriding, the samples were cross-sectioned and metallographically prepared. The thickness of the nitrided layer was measured by observations through scanning electron microscopy (SEM). Ten random surface hardness measurements were performed for each sample using a Vickers indenter, $25 \mathrm{~g}$ load and time test of $10 \mathrm{~s}$. The average value of measurements and standard deviation is reported. Wear resistance was evaluated by the pin-on-disk technique using a sapphire pin, $6 \mathrm{~mm}$ in diameter, and a load of $2 \mathrm{~N}$ at a speed of $20 \mathrm{~cm} / \mathrm{s}$ with a total displacement of $400 \mathrm{~m}$. The radius of attrition was set at $7 \mathrm{~mm}$ and the determination of the volume loss was carried out in accordance with the ASTM G99 standard method [16].

\section{Results and Discussion}

\subsection{Strain Grade and Crystallite Size Determination}

Figure 1 shows the XRD patterns obtained from untreated and plasma nitrided samples at different current densities $\left(1,1.5,2\right.$ and $\left.2.5 \mathrm{~mA} / \mathrm{cm}^{2}\right)$. The XRD pattern of untreated sample shows a typical $\gamma$-austenite phase. For all the nitride samples, XRD patterns showed that the $\gamma$-austenite peaks $[\gamma(111)$ and $\gamma(200)]$ were shifted to a lower $2 \theta$ angles, compared with the peaks from the untreated sample, suggesting a lattice deformation phenomenon and hence, showing the characteristic XRD pattern of the expanded austenite [17]. In fact, this shift has been re-

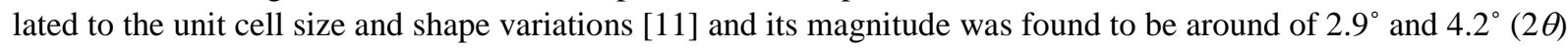
degrees for $\gamma^{\prime}(111)$ and $\gamma^{\prime}(200)$ peaks, respectively. These results are consistent with other investigations, in which is reported that the $\gamma^{\prime}(200)$ peak is shifted to the lower $2 \theta$ angles at higher grade than the $\gamma^{\prime}(111)$, relative to the untreated sample peaks [10] [18]. According to D. Manova this behavior is a consequence of the biaxial stress resulting in a perpendicular strain to the nitrided surface, thus increasing the lattice constant beyond the stress-free value. Both, the distorted lattice and the compressive stress contribute to the increased hardness and wear resistance of the nitriding samples [19].

Williamson and Hall relates the XRD peak broadening to surface micro strain and crystallite size through equation defining the FWHM as a key factor for its calculation [14]. The effect of nitriding current density on the evolution of strain grade and crystallite size, both calculated using above equation, are shown in Figure 2. Computed data shows that the crystallite size in the surface of the untreated sample is around $99 \mathrm{~nm}$ and it

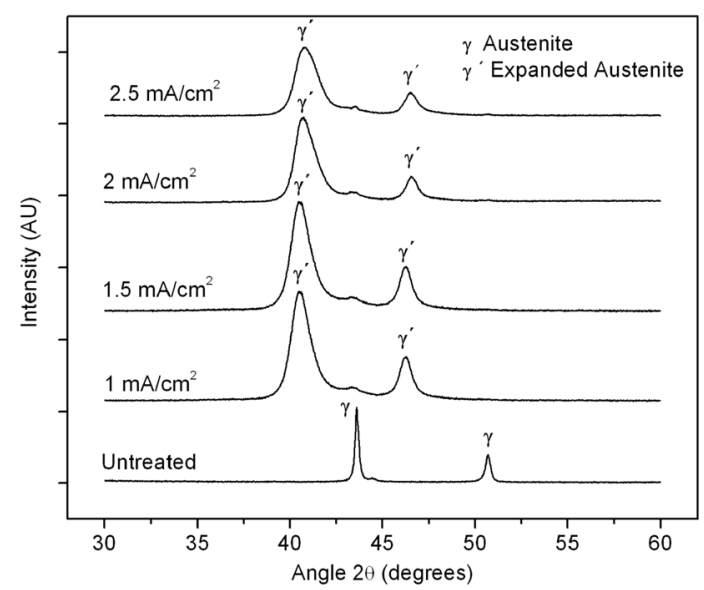

Figure 1. X-ray diffraction patterns for untreated and nitrided samples at different current densities. 


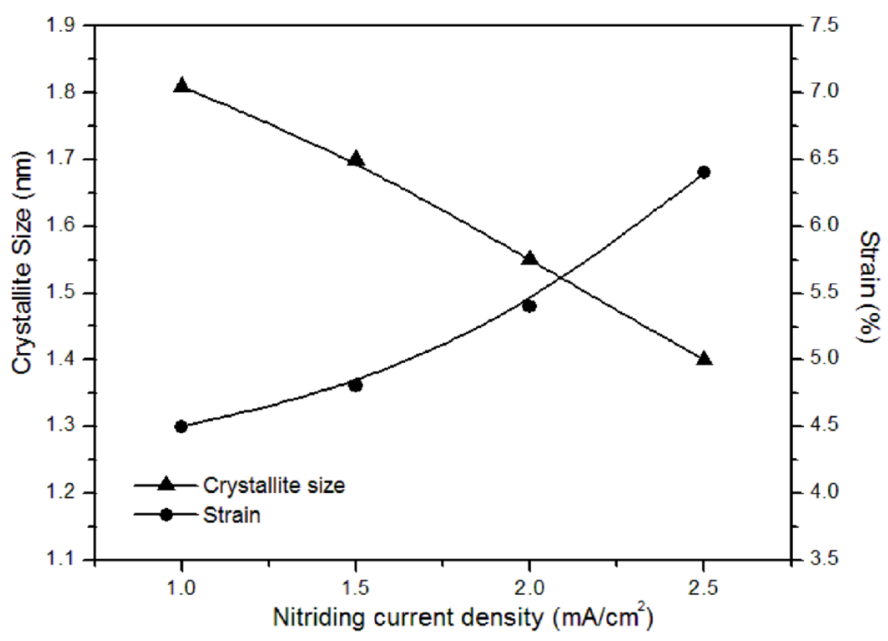

Figure 2. Influence of nitriding current density on strain (\%) and crystallite size $(\mathrm{nm})$ computed by Williamson-Hall methodology.

decreases dramatically to $1.8 \mathrm{~nm}$ when the sample is nitrided at $1 \mathrm{~mA} / \mathrm{cm}^{2}$, highlighting the effect of nitriding process on crystallite size. In contrast, the grain size seems not be affected by this process and therefore, it remain without changes (7.6 ASTM d $=25 \mu \mathrm{m}$ ). As Figure 2 shows, the increase in current density from 1 to 2.5 $\mathrm{mA} / \mathrm{cm}^{2}$ promotes a decrease in crystallite size from 1.8 to $1.4 \mathrm{~nm}$. In the same way, strain grade of nitrided surfaces increase from $4.5 \%$ to $6.5 \%$ when current density moves from 1 to $2.5 \mathrm{~mA} / \mathrm{cm}^{2}$. This behavior can be explained by the amount of nitrogen incorporated in the stainless steel surface. By increasing the current density of plasma discharge in the nitriding process, the population of active species $(\mathrm{N}+)$ in plasma near the surface of the samples is increased [20]; this phenomenon in turn allows a greater rate of incorporation of nitrogen atoms in the substrate and consequently, a greater strain level is obtained. An increase in atomic nitrogen quantity going inside to the steel also results in a greater grade of crystalline disorder and hence, a decrease of isotropic repeatability of the lattice will occur. As a result, smaller crystallite sizes (diffracting coherently domains) are generated.

Scanning Electron Microscopy cross view analysis of nitrided samples allowed the measurement of the modified surface thickness layer. Results show a decrease in thickness of nitrided layer from 4.6 to 3.4 microns when current density rises from 1 to $2.5 \mathrm{~mA} / \mathrm{cm}^{2}$ (see Figure 3). Despite the fact that both thickness layer and crystallite size decrease similarly when nitriding current density is increased, the behavior of the first can be explain in an independent way. In fact, a similar decrease in thickness layer of nitrided AISI 316L stainless steel has been reported by F. Borgioli et al. [21] when the nitriding current density increases from 1.2 to $2.7 \mathrm{~mA} / \mathrm{cm}^{2}$. In this case the variation in current density was carried out by increasing the treatment pressure. They concluded that sputtering phenomenon does not visibly influence the modified layer growth in the pressure range of 1.9 to 15 torr. However, at a treatment pressure of 1.13 torr (pressure very close to use in this work, 1.3 torr) sputtering seems to compete with the layer growth phenomena, tending to hinder nitrogen adsorption at the surface and diffusion into the bulk, so that a slight thinning of modified layer is produced. In the same way, previous studies have reported that the increase in current density in plasma processes promotes the intensification of sputtering phenomena [22].

\subsection{Hardness and Wear Resistance}

The combined effect of the increased surface strain grade and decrease in crystallite size, promoted the increase in surface hardness from $262 \mathrm{HV} 25 \mathrm{~g}$ for the untreated samples to around $1245 \mathrm{HV} 25 \mathrm{~g}$ for the nitrided samples at $1 \mathrm{~mA} / \mathrm{cm}^{2}$ (see Figure 4). Moreover, it has to be noted that when the current density increases from 1 to 2.5 $\mathrm{mA} / \mathrm{cm}^{2}$, the variation of the hardness does not change significantly and remains in values around of $1240 \mathrm{HV} 25$ g. At the same process conditions, volume loss evaluated by the pin-on-disk test was decreased from $0.3 \mathrm{~mm}^{3}$ for untreated samples to about $0.01 \mathrm{~mm}^{3}$ for nitrided samples, which represents a decrease level of about 30 times. 


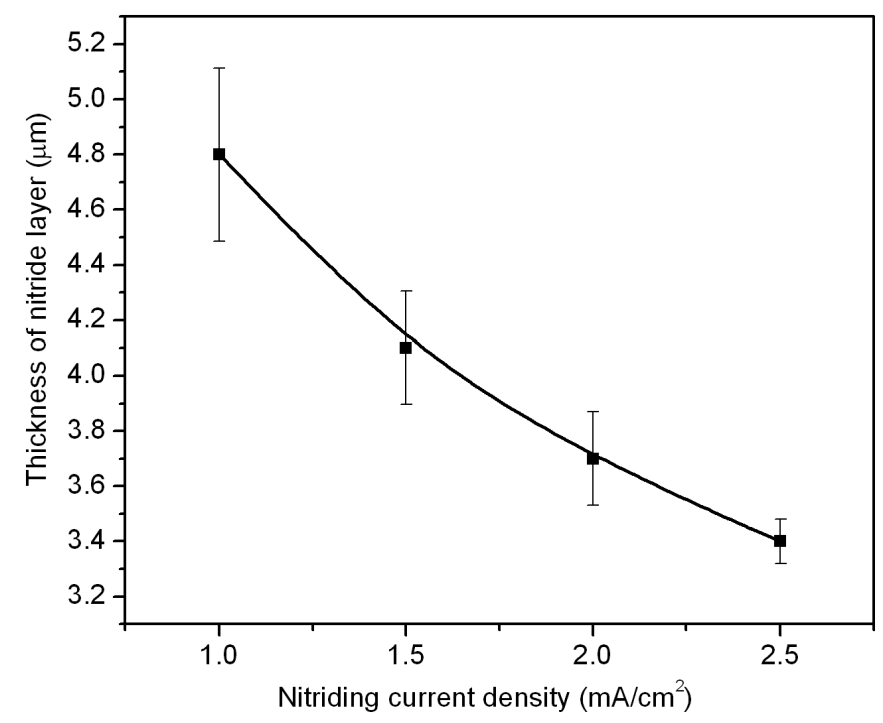

Figure 3. Effect of nitriding current density on thickness of nitrided layer. Vertical lines are the error bars and solid lines are only shown to emphasize the trends.

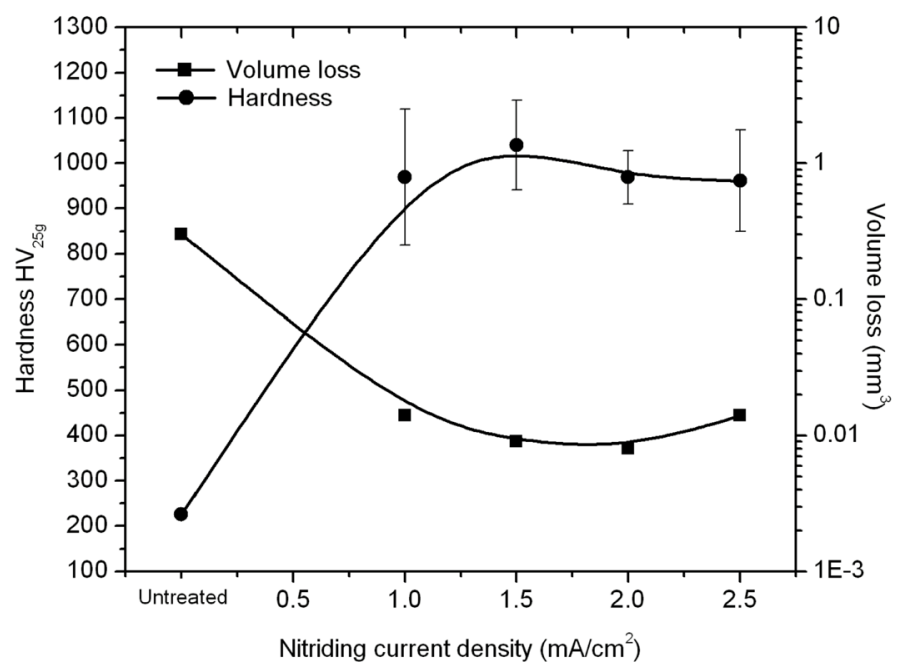

Figure 4. Influence of nitriding current density on surface hardness (HV25g) and volume loss $\left(\mathrm{mm}^{3}\right)$ measured by the pin-on-disk test.

\section{Conclusion}

Through ion nitriding treatment process carried out at $400^{\circ} \mathrm{C}$ and applying a nitriding current density in the range of $1-2.5 \mathrm{~mA} / \mathrm{cm}^{2}$ on AISI 316L stainless steel, it is possible to produce a hardness modified surface layer. According to the XRD data, the nitrided layer formed was mainly composed of expanded austenite phase. The use of Williamson-Hall methodology allowed the determination of crystallite size and strain grade. Results showed a decrease in crystallite size from $99 \mathrm{~nm}$ for untreated samples to $1.4 \mathrm{~nm}$ for samples nitrided at 2.5 $\mathrm{mA} / \mathrm{cm}^{2}$ promoted both: an increase in hardness from $262 \mathrm{HV} 25 \mathrm{~g}$ to $1245 \mathrm{HV} 25 \mathrm{~g}$, and a decrease in volume loss from $0.3 \mathrm{~mm}^{3}$ to about $0.01 \mathrm{~mm}^{3}$, which represents a wear decrease of about 30 times.

\section{Acknowledgements}

The authors acknowledge to support of "Corporación Mexicana de Investigación en Materiales S.A. de C.V." and to the "Fondo Sectorial de Innovación Secretaría de Economía-CONACYT (FINNOVA)". 


\section{References}

[1] Saleh, Z.B., Shahryari, A. and Omanovic, S. (2007) Enhancement of Corrosion Resistance of a Biomedical Grade 316LVM Stainless Steel by Potentiodynamic Cyclic Polarization. Thin Solid Films, 515, 4727-4737. http://dx.doi.org/10.1016/j.tsf.2006.11.054

[2] Meletis, E. (2002) Intensified Plasma-Assisted Processing: Science and Engineering. Surface and Coatings Technology, 149, 95-113. http://dx.doi.org/10.1016/S0257-8972(01)01441-4

[3] Tokaji, K., Kohyama, K. and Akita, M. (2004) Fatigue Behaviour and Fracture Mechanism of a 316 Stainless Steel Hardened by Carburizing. International Journal of Fatigue, 26, 543-551. http://dx.doi.org/10.1016/j.ijfatigue.2003.08.024

[4] Ceschini, L. and Minak, G. (2008) Fatigue Behaviour of Low Temperature Carburised AISI 316L Austenitic Stainless Steel. Surface and Coatings Technology, 202, 1778-1784. http://dx.doi.org/10.1016/j.surfcoat.2007.07.066

[5] Riviere, J.P., Templier, C., Declemy, A., Redjdal, O., Chumlyakov, Y. and Abrasonis, G. (2007) Microstructure of Expanded Austenite in Ion-Nitrided AISI 316L Single Crystals. Surface and Coatings Technology, 201, 8210-8214. http://dx.doi.org/10.1016/j.surfcoat.2006.01.080

[6] Mingolo, N., Tschiptschin, A.P. and Pinedo, C.E. (2006) On the Formation of Expanded Austenite during Plasma Nitriding of an AISI 316L Austenitic Stainless Steel. Surface and Coatings Technology, 201, 4215-4218. http://dx.doi.org/10.1016/j.surfcoat.2006.08.060

[7] Christiansen, T. and Somers, M.A.J. (2006) Metallurgical and Materials Transactions A, 37A, 675.

[8] Gontijo, L.C., Machado, R., Miola, E.J., Catselleti, L.C., Alcantara, N.G. and Nascente, P.A.P. (2006) Study of the S Phase Formed on Plasma-Nitrided AISI 316L Stainless Steel. Materials Science and Engineering: A, 431, 315-321. http://dx.doi.org/10.1016/j.msea.2006.06.023

[9] Oddershede, J., Christiansen, T.L. and Ståhl, K. (2008) Modelling the X-Ray Powder Diffraction of Nitrogen-Expanded Austenite Using the Debye Formula. Journal of Applied Crystallography, 41, 537-543. http://dx.doi.org/10.1107/S0021889808005943

[10] Jiang, J.C. and Meletis, I. (2000) Microstructure of the Nitride Layer of AISI 316 Stainless Steel Produced by Intensified Plasma Assisted Processing. Journal of Applied Physics, 88, 4026. http://dx.doi.org/10.1063/1.1289476

[11] Pielaszek, J. (2002) In: Knauth, P. et al., Eds., Nanostructured Materials. Selected Synthesis Methods, Properties and Applications, Kluwer Academic Publishers, New York.

[12] Nosei, L., Farina, S., Ávalos, M., Náchez, L., Gómez, B.J. and Feugeas, J. (2008) Corrosion Behavior of Ion Nitrided AISI 316L Stainless Steel. Thin Solid Films, 516, 1044-1050. http://dx.doi.org/10.1016/j.tsf.2007.08.072

[13] Díaz Guillén, J.C., Campa Castilla, A., Pérez Aguilar, S.I., Granda Gutiérrez, E.E., Garza Gómez, A., Candelas Ramírez, J. and Méndez Méndez, R. (2009) Superfcies y Vacío, 21, 1.

[14] Williamson, G.K. and Hall, W.H. (1953) Acta Metall., 1, 23-31.

[15] Saravanan, P., Raja, V.S. and Mukherjee, S. (2007) Effect of Plasma Immersion Ion Implantation of Nitrogen on the Wear and Corrosion Behavior of 316LVM Stainless Steel. Surface and Coatings Technology, 201, 8131-8135. http://dx.doi.org/10.1016/j.surfcoat.2006.08.149

[16] ASTM G99 Standard Test Method for Wear Testing with a Pin-on-Disk Apparatus. ASTM Standard. (2010).

[17] Marchev, K., Landis, M., Vallerio, R., Cooper, C.V. and Giessen, B.C. (1999) The $m$ Phase Layer on ion Nitrided Austenitic Stainless Steel (III): An Epitaxial Relationship between the $m$ Phase and the $\gamma$ Parent Phase and a Review of Structural Identifications of This Phase. Surface and Coatings Technology, 116, 184-188. http://dx.doi.org/10.1016/S0257-8972(99)00296-0

[18] Abrasonis, G., Riviere, J.P., Templier, C., Pranevicius, L. and Barradas, N.P. (2005) Journal of Applied Physics, 97, 124906. http://dx.doi.org/10.1063/1.1929093

[19] Manova, D., Lutz, J., Gerlach, J.W., Neumann, H. and Mändl, S. (2012) Surf. Coat. Tech., 5, S290.

[20] Granda-Gutiérrez, E.E., López-Callejas, R., Peña-Eguiluz, R., Valencia, R.A., Mercado-Cabrera, A., Barocio, S.R., de la Piedad-Beneitez, A., Benítez-Read, J.S. and Pacheco-Sotelo, J.O. (2008) V-I Curves and Plasma Parameters in a High Density DC Glow Discharge Generated by a Current-Source. Journal of Physics: Conference Series, 100, 062019. http://dx.doi.org/10.1088/1742-6596/100/6/062019

[21] Borgioli, F., Fossati, A., Galvanetto, E., Bacci, T. and Pradelli, G. (2006) Glow Discharge Nitriding of AISI 316L Austenitic Stainless Steel: Influence of Treatment Pressure. Surface and Coatings Technology, 200, 5505-5513. http://dx.doi.org/10.1016/j.surfcoat.2005.07.073

[22] Barhai, P.K., Kumari, N., Banerjee, I., Pabi, S.K. and Mahapatra, S.K. (2010) Study of the Effect of Plasma Current 
Density on the Formation of Titanium Nitride and Titanium Oxynitride Thin Films Prepared by Reactive DC Magnetron Sputtering. Vacuum, 84, 896-901. http://dx.doi.org/10.1016/j.vacuum.2009.12.004

[23] Ruset, C., Ciuca, S. and Grigore, E. (2003) The Influence of the Sputtering Process on the Constitution of the Compound Layers Obtained by Plasma Nitriding. Surface and Coatings Technology, 174-175, 1201-1205.

http://dx.doi.org/10.1016/S0257-8972(03)00589-9 